\title{
Şehir İçi Ana Arterlerde COVID-19 \\ Kisıtlamalarından Dolayı Trafik Akımlarında Meydana Gelen Değişimlerin İncelenmesi: Antalya Örneği
}

\author{
Eren Dağl $1^{1}$ \\ Metin Mutlu Aydin ${ }^{2}$ \\ ORCID:0000-0002-3892-0270 \\ ORCID:0000-0001-9470-716X \\ Emine Çoruh ${ }^{3}$
}

ORCID: 0000-0002-3251-9179

\section{Öz}

2019 yılı sonunda Çin'de ortaya çıkan COVID-19 Pandemisi, 2020 yılının ilk aylarından itibaren Dünya genelinde birçok alanda kısıtlamalara ve düzen değişikliklerine neden olmuştur. Diğer tüm alanlarda olduğu gibi ulaştırma hizmetleri ve ulaşım karakteristiklerinde de bu pandemi nedeniyle büyük değişiklikler görülmüştür. Ülkemizde pandeminin görülmeye başlandığı tarihten itibaren pandeminin seyrine ve virüse yakalanan vatandaş sayısındaki artışa bağh olarak bazı dönemlerde sokă̆a çıkma kısıtlamaları getirilmiştir. Bu kısıtlamalara bağhı olarak toplu taşıma sefer sıklıkları, şehir içi ve şehirlerarası toplu taşıma hizmetlerini kullanan yolcu sayıları, trafikteki araç sayısı vb. ulaşım ile ilgili birçok alanda değişiklikler görülmeye başlanmıştır. Bu çalışma kapsamında, pilot kent olarak seçilen Antalya şehir merkezinde yer alan ana arterler üzerinde pandemi etkisi nedeniyle trafikteki araç sayısında meydana gelen değişimler incelenmiştir. Elde edilen sonuçlar detaylı olarak irdelendiğinde, pandemi sırasında kısıtlama günlerinde araç sayısında önemli derecede azalmalar görülmüştür. Yine elde edilen sonuçlara göre, ülkemizde trafiğe çıkan araç saylsında artış meydana gelmesine rağmen, kısıtlama günleri dışındaki günlerde trafikteki araç sayısının pandemi öncesindeki sayıya yakın olduğu görülmüştür. Bu sonuç, pandemi nedeniyle sürücülerin toplu taşıma yerine bireysel araç kullanımına yöneldiklerini doğrulamaktadır.

Anahtar Kelimeler: Ana arter, araç sayısı, COVID-19 pandemisi, trafik akım değişimi.

\footnotetext{
${ }^{1}$ Öğr. Gör., Selçuk Üniversitesi, E-mail:eren.dagli@selcuk.edu.tr

${ }^{2}$ Doç. Dr., Ondokuz Mayıs Üniversitesi, E-mail:metinmutluaydin@gmail.com

${ }^{3}$ Dr. Öğr. Üyesi, Gümüşhane Üniversitesi, E-mail:eminecoruh@gumushane.edu.tr

idealkent @ Kent Araştırmaları Dergisi (Journal of Urban Studies)

http://idealkentdergisi.com

Geliş Tarihi Received Date: 23.09.2021 Kabul Tarihi Accepted Date: 26.12.2021
} 


\title{
Investigation of Changes in Traffic Flows due to COVID-19 Restrictions in Urban Main Arterials: Example of Antalya
}

\author{
$*$ \\ Eren Dağ $1^{4}$
ORCID:0000-0002-3892-0270 \\ Metin Mutlu Aydın 5 \\ Emine Çoruh ${ }^{6}$ \\ ORCID: 0000-0002-3251-9179
}

\begin{abstract}
The COVID-19 pandemic, which appeared in China at the end of 2019, has led to restrictions and changes in worldwide since the first months of 2020. As in all other areas, there have been changes in transportation services and characteristics. Lockdown restrictions have been imposed in some periods, depending on pandemic and increase in the number of citizens infected from virus since the beginning of the pandemic in Turkey. Due to restrictions, changes have started to be observed in many areas related to transportation, such as the frequency of public transportation services, the number of passengers transportation services, and the number of vehicles in traffic. In the study, changes in the number of vehicles caused by the pandemic on the main arterials in Antalya city, which was selected as the pilot city, were investigated. When the results were examined, it was observed that the number of vehicles decreased importantly in the restriction days. According to the results, it was also revealed that the number of vehicles in traffic on the days other than restriction days was close to the number before the pandemic. This confirms that drivers are choosing individual vehicle use instead of public transportation due to the pandemic.
\end{abstract}

Keywords: Main arterial, vehicle number, COVID-19 pandemic, traffic flow change

${ }^{4}$ Lecturer, Selcuk University, E-mail:eren.dagli@selcuk.edu.tr

${ }^{5}$ Assoc. Prof., Ondokuz Mayis University, E-mail:metinmutluaydin@gmail.com

${ }^{6}$ Asst. Prof., Gumushane University, E-mail:eminecoruh@gumushane.edu.tr

idealkent @ C Kent Araştırmaları Dergisi (Journal of Urban Studies)

http://idealkentdergisi.com

Geliş Tarihi Received Date: 23.09.2021 Kabul Tarihi Accepted Date: 26.12.2021 


\section{Giriş}

İnsanlık tarihi boyunca pek çok kez çeşitli ülkelere, hatta kıtalara yayılan ve etkisini geniş bir alanda gösteren hastalıklar görülmüş, bu hastalıklar pandemi olarak ifade edilmiştir. Geçmişten günümüze farklı zaman aralıklarında ve farklı yıkıcı etkilere sahip Ebola, Domuz Gribi, Sars, İspanyol Gribi, Kara Veba, Sarı Humma, HIV/AIDS gibi çeşitli salgınlar görülmüştür. Yaygin bir etkiye sahip olan bu salgınlar ne yazık ki milyonlarca kişinin ölümüne sebebiyet vermiştir (World Health Organization [WHO], 2020). Benzer bir küresel salgın 2019 yılının son çeyreğinde Çin'in Wuhan kentinde ortaya çımış ve kısa sürede tüm dünyayı etkisine almıştır. Daha önce SARS-CoV-2 olarak tanımlanan ve 118 bin vaka ve 4291 kişinin ölümüne sebebiyet veren bu virüs, Dünya Sağlık Örgütü (DSÖ) tarafından 11 Mart 2020 tarihinde COVID-19 Pandemisi olarak ilan edilmiştir (WHO, 2020). COVID-19 salgını her ne kadar tüm dünyayı 2020 başlarında etkisi altına alsa da Türkiye gibi bazı ülkelerde uzun süre pozitif vakaya rastlanılmamıştır. Ancak, DSÖ tarafindan pandeminin ilan edildiği gün olan 11 Mart 2020 tarihinde, Türkiye'de de ilk COVID-19 vakasına tespit edilmiştir (Bbc, 2021).

Pandemi başlangıcından itibaren yetkililer bir yandan sağlık altyapısı ile tedavi hizmetleri sunmaya çalışırken, bir yandan da pandeminin etkilerini azaltıcı arayışlar içerisine girmişlerdir. Bu arayışlardan birisi de insanların çok fazla etkileşim içerisinde olduğu ulaştırma sistemleridir. Özellikle, toplu taşıma sistemlerindeki yoğunluğu azaltmak ve gerekli bireysel koruma alanını oluşturabilmek amaciyla toplu taşıma sistemlerinde yapılan kontrol ve düzenlemeler de pandeminin seyrinde önemli bir yere sahip olmuştur. Yapılan araştırmalardan, pandemi süresince yetkililer tarafından sosyal alanlarda alınan tedbir ve kısıtlamalarla birlikte uzaktan eğitim ve çalışma uygulamaları sayesinde kent içi hareketlilikte önemli bir azalma eğilimi olduğu görülmüştür (Arslan ve Murat, 2011; De Vos, 2020; Liu ve Stern, 2021; Mutlu, Durak ve Akyer, 2021).

Türkiye'de 2021 yılı nisan ayına ait motorlu kara taşıtları bülteni incelendiğinde, bir önceki yılın aynı dönemine göre trafik kaydı yapılan araç sayısında \%155 oranında bir artış olduğu görülmüştür (Türkiye İstatistik Kurumu [TÜİK], 2021). Mevcut istatistikler, her geçen gün trafiğe çıkan araç sayısında önemli artış olduğunu gösterse de pandemi döneminde tedbir amaçlı şehir içi hareketini azaltan ve mümkün olduğunca evde kalan vatandaşların, bu tercihlerinin trafik yoğunluğunun stabil kalmasında önemli bir etkisinin 
olduğu söylenebilmektedir. Özellikle pandemi döneminde konulan kısıtlamalar, pandeminin evden çalışmaya yönlendirmesi vb. durumlara bağlı olarak şehir içi arterlerdeki araç sayılarında sürekli değişkenlik görüldüğü tespit edilmiştir. Bu dönemdeki değişken trafik akım değerlerinin gerçek bir yol planlama sürecinde etkin şekilde kullanılamayacağı oldukça açıktır ve bu nedenle kısıtlamalar dolayısıyla şehir içi yollardaki ulaşım hareketliliğinde meydana gelen bu değişimleri sayısal olarak bilmek planlama çalışmalarında karar verebilmek için oldukça önemlidir. Bu kapsamda özellikle kısıtlamanın, toplu ulaşımdaki talebin düşmesi, bireysel araç kullanımının artması vb. nedenlerle şehirlerin ana arterlerindeki mevcut trafik akım değerlerinde görülen değişimlerin açık bir şekilde ortaya konulması, planlama çalışmaları için oldukça önemlidir. Bu amaçla çalışma kapsamında pandemi ve kısıtlama dönemlerindeki ana arterlerdeki trafik akım karakteristiklerinin bilimsel olarak irdelenebilmesi amaciyla pilot kent olarak Antalya seçilmiştir. Antalya kent merkezinde bulunan ana arterlerde trafik akım değişimleri farklı zamanlarda ve düzenli olarak yapılan saha gözlemleri ile ortaya konulmaya çalışlarak, salgının başlangıcından itibaren alınan tedbirler ve düzenlemelere göre şehir merkezinde trafik akım değerlerindeki değişim nicel olarak elde edilmiştir. Salgın döneminde elde edilen bu sonuçların ileride yapılacak ulaşım planlama çalışmalarında kullanılabilecek önemli bir kaynak olması beklenmektedir. Özellikle elde edilen sonuçların, ileride yaşanabilecek yeni salgınlar için ya da mevcut salgın durumunun beklenenden uzun sürmesi durumunda nasıl planlamalar yapılması gerektiği hususunda kullanılabilecek bir altlık olabileceği öngörülmektedir.

\section{Literatür}

COVID-19 pandemisinin etkisinin küresel ölçekte etkisini göstermesiyle birlikte araştırmacılar, ulaşım hareketliliği ile şehiriçi ve şehirlerarası trafik akımı üzerindeki etkilerini incelemeye; ulaşım plancları ise görülen etkilere göre farklı kararlar almaya başlamışladır. Chinazzi, Davis, Ajelli, Gioannini, Litvinova, Merler, ve Vespignani (2020) yapmış oldukları çalışmada, COVID-19'un ilk çıkış noktası olan Wuhan'da yetkililer tarafından alınan tedbir ve kısıtlamaların yolculuk vb. ulaşım hareketliliğini önemli ölçüde azalttığını ve bu durumun vaka sayılarının azalmasında önemli katkılar sağladığını ortaya koymuştur. Pandemi süresince yetkililer ise, tedbir ve kısıtlamaların yanı sıra salgınla mücadelede etkin faktörlerden birisi olan genel sokağa çıkma yasakları uygulamalarına gitmişlerdir. Bu kapsamda, COVID-19 
pandemisinin etkisini arttırmasıyla birlikte Belçika, Fransa, İtalya, İngiltere, Almanya ve diğer birçok Avrupa ülkesi sert kısıtlamalar ve sokağa çıkma yasakları uygulamaya başlamıştır (Euronews, 2020). Ancak uygulanan yasaklar, pandemiyi yavaşlatsa da ekonomik problemlerin yanı sıra insanlarda panik ve psikolojik problemlere de neden olmuştur (Guan, Prieur, Zhang, Prieur, Georges, ve Bellemain, 2020). Andara, Ortego-Osa, Gómez-Caicedo, Ramírez-Pisco, Navas-Gracia, Vásquez, ve Gaitán-Angulo (2021) pandeminin araç kullanım ve toplu taşıma üzerine etkisini incelemek üzere yürüttükleri çalışmada, insanların pandeminin psikolojik etkisi ile bireysel araç kullanımına yöneldiğini ve toplu taşıma araçlarının tercih edilirliğinde düşüşler olduğunu belirlemişlerdir. Benzer şekilde, Türkiye'de de yapılan araştırmalarda da toplu taşıma tercih edilirliğinde büyük düşüşler olduğu tespit edilmiştir (Erbaş, 2020; İstanbul İstatistik Ofisi [İ̈O], 2020). Salgının ilk pik dönemine gelen ancak kısıtlamaların yoğun olmadığı tarihlerde, Amerika'daki büyük kentlerde bireysel araç kullanımının artmasına bağlı olarak trafik sıkışıklıklarında da önemli artışlar olduğu görülmüştür (Andara ve diğerleri, 2021). Avustralya'da yürütülen başka bir çalışmada ise Beck ve Hensher (2020), kısıtlamalar nedeniyle hane haklarındaki yolculuk sayısının büyük bir azalma gösterdiğini, kısıtlamalar kalkınca seçilen ulaşım türlerinde farklılıklar olduğunu belirlemişlerdir. Benzer bir çalışmada Abu-Rayash ve Dincer (2020) küresel hava yolculuğu talebinde de kisttlamalar ve düzenlemeler nedeniyle ardışık şekilde düzenli azalmalar meydana geldiğini belirtmişler ve bunun sürpriz bir sonuç olmadığına dikkat çekmişlerdir. COVID-29 pandemisinin kısıtlamalar nedeniyle doğrudan trafik üzerine etkisi karar vericiler, plancılar, enstitüler vb. ulaşım konusunda ilgililer tarafından izlenerek azalmanın miktarı nicel olarak belirlenmeye çalışılmıştır (Brookings Institute, 2020; Institute of Transportation Engineers, 2020; Mission Support Services, 2020; University of Maryland, 2020).

Elde edilen gözlem sonuçlarına göre salgının Dünya genelinde kabul gördüğü ilk üç ay içerisinde ABD'de yaklaşık olarak \%30 ile \%50 arasında bir azalma görülmüştür. Eyalet bazında daha detaylı örnek bir çalışmada Goenaga, Matini, Karanam, ve Underwood (2021) Kuzey Karolina ve Virginia eyaletlerinde bu azalmanın değerini yaklaşık olarak \%27 tespit etmiş̧ir. Yine aynı çalışma kapsamında yapılan incelemelerde evde-kal kısıtlamalarının başında trafik akım miktarında hafif bir artış olduğu sonrasında ise \%40'lara varan azalmalar olduğu belirlenmiştir. Kısıtlama başlangıcında görülen bu hafif artış üzerinde insanların gıda vb. temel ihtiyaç malzemesi stoklamak için yolculuk yapması ana neden olarak gösterilmektedir. 
COVID-19 pandemisinin kapanmaya neden olması ve bunun bir etkisi olarak, pandemi döneminde bireysel motorlu araç kullanımının yanı sıra bisiklet de tercih edilen diğer bir ulaşım aracı olup, bu şekilde daha çevreci hareketlilik sağlandığ1 belirlenmiştir (Aloi, Alonso, Benavente, Cordera, Echániz, González, ve Sañudo, 2020). Yapmış oldukları çalışmada Huang, Ding, Gao, Zheng, Zhou, Qi, ve He, (2021) ile Le Quéré, Jackson, Jones, Smith, Abernethy, Andrew ve Peters, (2020), kısıtlamalar ve ulaşım sistemlerindeki tedbirlerin etkisi ile ulaşım aktivitelerinde meydana gelen azalmalara bağlı olarak ulaşım kaynaklı hava kirliliği ayrıca emisyon değerlerinde keskin düşüşler olduğunu belirlemişlerdir. Tian X., An, Chen, ve Tian Z., (2021) ise Kanada'da şehir içi ulaşım ve hava kirliliği üzerine yaptıkları çalışmada pandeminin etkisinin yoğun olarak hissedildiği ve yaklaşık ilk pik dönem olan 2020 yılı nisan ayında karbondioksit değerlerinin en düşük seviyeye geldiğini tespit etmişlerdir. Literatürdeki mevcut diğer çalışmalar da incelendiğinde, genel olarak pandemi süreciyle birlikte insanların ulaşım alanında da farklı tutum ve davranışlar sergiledikleri aşikârdır. Sokağa çıkma yasağı ve etkin k1sitlamaların olduğu dönemlerde hem toplu taşıma doluluk oranlarında hem de trafik yoğunluğunda bariz azalmalar olduğunu net şekilde görülmüştür (Kopsidas, Milioti, Kepaptsoglou ve Vlachogiann, 2021). Pandemi süresince toplumun ulaşım alışkanlıklarında meydana gelen değişimler doğrudan ulaşım ekonomisini de olumsuz etkilemektedir. Pandemi süresince toplu taşıma tercih edilirliğinin düşmesi ile maliyetler aynı kalırken gelirlerde büyük bir düşüş olduğu görülmüş ve bu durum sürdürülebilirlik açısından kritik bir problem olmuştur. Bu kapsamda Ekergil ve Kodalak (2020) yapmış oldukları çalışmada, Eskişehir ili özelinde raylı sistem bölgesel tarife önerisi ile COVID19'un devam etmesi halinde karşılaşılabilecek işletim problemlerine karşı farklı ve yeni bir fiyatlandırma politikası önermişlerdir. Benzer şekilde Cruz ve Sarmento (2021) yaptıkları çalışmada Portekiz'deki Brisa otoyolunda COVID-19'un bölgede etkisini hissettirmesi ile birlikte trafik miktarında düşüşler gözlemlendiğini, nisan ayında ise sokağa çıkma kısıtlamaları ile birlikte \%70'e varan düşüşler olduğunu belirtmişlerdir. Bu durumun otoyol, köprü işleten firmalar açısından büyük ekonomik kayıplara sebebiyet verdiğini ve virüsten kaynaklı yeni ekonomik tedbirler almaya yönelmenin gerektiğine dikkat çekmişlerdir.

Mevcut literatür incelendiğinde pandemi sonrası Dünya genelinde araştırmacıların kendi ülke, bölge ya da şehirlerinde salgın etkisi ile trafik akım miktarında ya da yolculuk sayılarında meydana gelen değişimleri sayısal olarak ortaya koymaya çalışmıştır. Mevcut bu çalışmalar değişim sonuçlarını 
daha çok genel olarak ifade yoluna giderken, bu çalışma da salgının başından itibaren gün ve ay bazlı olarak daha detaylı bir inceleme yoluna gidilmiştir. Yapılan bu detaylı inceleme ile literatürden farklı olarak özellikle her ülkenin birbirinden bağımsız olarak belirlediği kısıtlamaların etkisinin ülkelere göre nasıl değişiklik gösterebileceği, Türkiye'deki bir kent örneği ile ortaya konulmaya çalışılmıştır. Bu amaçla kısıtlamaların özellikle hafta sonu ağırlıklı olduğu Türkiye için tüm günlerdeki değişimler belirlenerek, hafta içi ve hafta sonundaki farklılık net bir şekilde ortaya konulmuştur. Böylece gün bazlı k1sıtlamaların nasıl bir etki oluşturduğu belirlenmiştir.

\section{Yöntem}

Virüsün ülkemizde ilk kez 11 Mart 2020 tarihi itibari ile görülmesiyle birlikte yayılımının sinırlandırılabilmesi ve kontrol altına alınabilmesi amacıyla 16 Mart 2020 tarihi itibari ile yüz yüze eğitime ara verilmiştir. İlerleyen günlerde de pandemi süresince hayatımızın bir parçası olan kısıtlamalar ilk olarak 65 yaş üstü vatandaşlar için olmak üzere kademeli olarak farklı yaş ve meslek grupları için getirilmiştir. Yine bu süreçte esnek çalışma yöntemi uygulanmaya başlanarak hareketlilik sınırlandırılmaya çalışılmıştır. 23 Mart 2020 tarihi itibari ile de tüm şehir içi toplu taşıma araçlarında kapasite sınırlaması getirilerek \%50 kapasite ile yolcu taşınmasına izin verilmiştir. Tüm bu çabalara rağmen 1 Nisan 2020 tarihine gelindiğinde ülkemizde 15679 vaka tespit edilmiş ve bu nedenle 3 Nisan 2020 itibari ile 20 yaş altı vatandaşlar için de 65 yaş üstü vatandaşlarda olduğu gibi sokağa çıkma kısıtlaması kararı alınmıştır (Türkiye Cumhuriyeti Sağlık Bakanlığı, 2020). Ayrıca şehirlerarası seyahat ile pozitif vakaların ülke geneline yayılmasını engellemek amacıyla 30 büyükşehir ve çok aşırı vaka yoğunluğu gözlemlenen Zonguldak ili için seyahat kısıtlaması getirilmiştir. Bu sürece kadar alınan tüm önlemlere rağmen, 10 Nisan 2020 tarihine gelindiğinde Türkiye Cumhuriyeti Sağlık Bakanlığı verilerine göre 47029 COVID-19 vakası tespit edilmiştir. Dünya genelinde birçok ülkede olduğu gibi ülkemizde de yaş sınırlaması olmaksızın 30 büyükşehir ve Zonguldak ili için 11-12 Nisan 2020 tarihlerinde (hafta sonu) ilk kez sokağa çıkma yasağı ilan edilmiş̧tir (Türkiye Cumhuriyeti Sağlık Bakanlığı, 2020).

Belirli yaş kesimlerine uygulanan sokağa çıkma kısıtlaması, yüz yüze eğitime ara verilmesi ve kısmi zamanlı çalışma uygulamaları ile gün içerisinde hareketlilik içerisinde bulunan nüfus miktarı azaltılmaya çalışılmıştır. Şehiriçi toplu taşıma araçlarında uygulanan \%50 kapasite sınırlaması ile de Sağlık 
Bakanlığı Koronavirüs Bilim Kurulu'nun benimsemiş olduğu "sosyal mesafe" sağlanmaya çalışılmıştır. Yetkililerin almış oldukları önlemler ve yapılan düzenlemelerin yanı sıra toplumun davranısı da salgının seyrini belirleyecek en önemli etkendir. Bu süreçte kısıtlamaların yanında insanlarda oluşan panik algısının da etkisi ile vatandaşların toplu taşıma kullanım verileri incelendiğinde çok ciddi düşüşler olduğu gözlemlenmektedir. Tablo 1'de verilen ve Türkiye'nin en kalabalık şehri olan İstanbul'a ait toplu taşımadaki yolculuk miktarları incelendiğinde, 2020 yılında pandeminin hemen öncesindeki iki ay (ocak ve şubat) ile pandeminin görüldüğü ilk iki aya (mart ve nisan) ait veriler incelendiğinde yolculuk sayılarında önemli azalmalar olduğu görülmüştür (İ̈O, 2020).

Tablo 1. İstanbul ili için Covid-19 başlangıcındaki yolculuk miktarlarındaki değişim (İ̈O, 2020)

\begin{tabular}{lllll}
\hline \multirow{2}{*}{ Yolcu Türü } & \multicolumn{4}{l}{ Toplam Yolculuk Miktarlan } \\
\cline { 2 - 5 } & Ocak 2020 & Şubat 2020 & Mart 2020 & Nisan 2020 \\
\hline Vatandaş & 102.239 .630 & 94.701 .785 & 63.043 .922 & 15.970 .553 \\
Öğrenci & 72.323 .146 & 76.805 .622 & 46.634 .160 & 4.459 .672 \\
60 Yaş Üstü & 16.490 .422 & 16.511 .022 & 10.183 .478 & 633.678 \\
Engelli & 4.671 .645 & 4.652 .158 & 3.360 .330 & 880.622 \\
Toplam $(\Sigma)$ & 195.724 .843 & 192.670 .587 & 123.221 .890 & 21.944 .525 \\
\hline
\end{tabular}

Covid-19 pandemisi, başlangıç döneminden itibaren insanların toplu taşıma kullanım alışkanlıklarında değişimlere neden olmuş ve bulaş ihtimali korkusu ile vatandaşları bireysel araç kullanımına yönlendirmiştir. Her ne kadar bulaş riskine karşı insanlar bireysel araç kullanımına yönelse de Şekil 1 ve Tablo 2'de görüldüğü üzere toplu taşımada olduğu gibi bireysel araç hareketliliğinde de Covid-19 başlangıcından itibaren azalmalar gözlemlenmektedir.

Örnek olarak Türkiye'nin en kalabalık şehri olan İstanbul incelendiğinde, 11-12; 18-19 ve 25-26 Nisan 2020 tarihlerinde hafta sonu uygulanan sokağa çıkma kısıtlamalarının bariz etkisi ile mart ayında ana arterlerdeki araç sayılarında ortalama \%16,7, nisan ayında ise ortalama $\% 52,9$ azalma olduğu görülmüştür (IİO, 2020). 


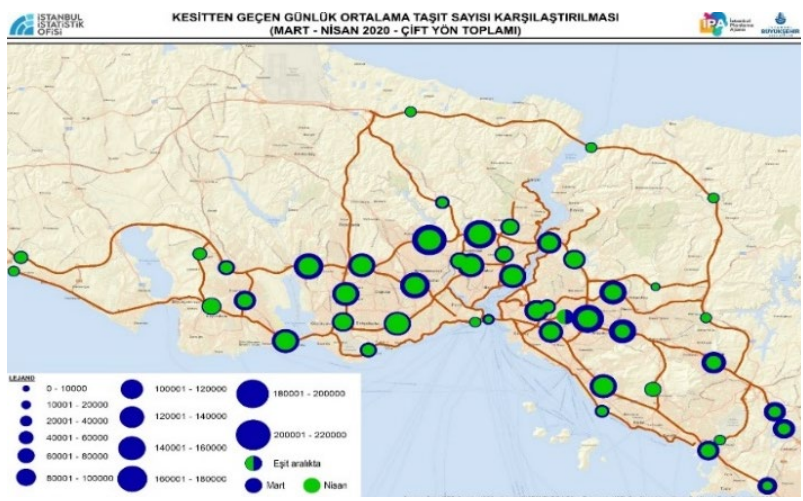

Şekil 1. Kesitten geçen günlük ortalama taşıt sayısı karşılaştırılması (İ̈O, 2020)

Tablo 2. İstanbul için COVID-19 başlangıcındaki ortalama araç sayıları değişimi (İ̈, 2020)

\begin{tabular}{lll}
\hline \multirow{2}{*}{ Gün } & \multicolumn{2}{l}{ Araç Sayılarındaki Değişim (\%) } \\
\cline { 2 - 3 } & Mart & Nisan \\
\hline Pazartesi & $\%-19.3$ & $\%-34.9$ \\
Salı & $\%-19.5$ & $\%-35.4$ \\
Çarşamba & $\%-18.4$ & $\%-38.1$ \\
Perşembe & $\%-18.3$ & $\%-48.3$ \\
Cuma & $\%-19.0$ & $\%-51.3$ \\
\hline Hafta içi & $\%-18.1$ & $\%-41.4$ \\
\hline Cumartesi & $\%-12.7$ & $\%-83.2$ \\
Pazar & $\%-15.9$ & $\%-88.5$ \\
\hline Hafta sonu & $\%-12.8$ & $\%-85.5$ \\
\hline Ortalama & $\%-16.7$ & $\%-52.9$ \\
\hline
\end{tabular}

Mevcut istatistikler incelendiğinde, Covid-19 pandemisi nedeniyle pandemi başlangıcından itibaren insanların hem ulaşım tercihlerinde hem de yolculuk sayılarında önemli değişmeler ve azalmalar olduğu görülmektedir. Bu sonuç özellikle planlama yapılırken araç sayılarındaki ve ulaşım türlerindeki bu değişimin dikkate alınmasının gerekliliği bir kez daha ön plana ç1karmaktadır.

Çalışma kapsamında adrese dayalı nüfus kayıt sistemi verilerine göre 2020 yılı sonu nüfusu 2.548.308 kişi ile Türkiye'nin en kalabalık beşinci şehri olan ve aynı zamanda Nisan 2021 itibari ile trafiğe kayıtlı 1.177.097 araç sayısı ile İstanbul, Ankara ve İzmir'in ardından dördüncü sırada yer alan Antalya ili pilot şehir olarak seçilmiştir (TÜiK, 2021). Çalışmada pilot bölge olarak belir- 
lenen Antalya il merkezinde, şehrin doğu ve batı bölgelerindeki vatandaşların yoğun olarak kullandığı ve günün her saatinde araç akışı gözlemlenen iki farklı ana arterdeki toplam dört farklı nokta belirlenmiştir. Bu noktalardan ilk ikisi (Nokta 1 ve Nokta 2) Atatürk Bulvarı üzerinde, diğer ikisi (Nokta 3 ve Nokta 4) ise Bülent Ecevit bulvarı üzerinde yer almaktadır ve konumları ise Şekil 2'de verilmektedir.

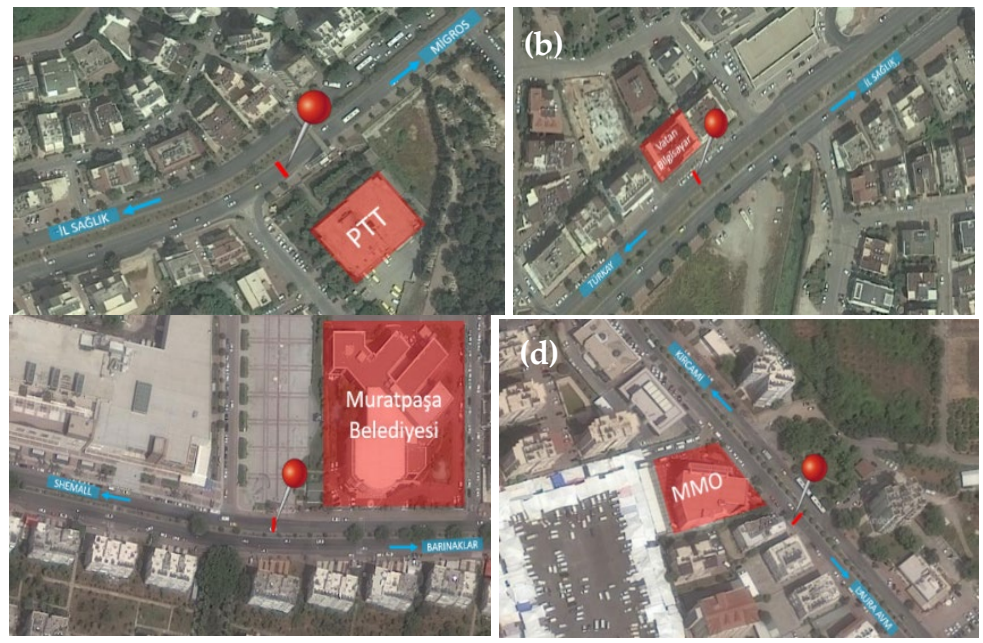

Şekil 2. (a) 1 numaralı (b) 2 numaralı (c) 3 numaralı ve (d) 4 numaralı gözlem noktalarınin konumları

\section{Verilerin Toplanması}

Çalışma kapsamında pilot kent olarak belirlenen Antalya ilinde seçilen dört noktada yer alan yol kesimlerindeki araç sayılarını tespit edebilmek amaciyla 2020 yılı eylül ayından 2021 yılı mayıs ayına kadar farklı gün ve zaman dilimlerinde video kamera çekimleri ile saha gözlemleri (hibrit yöntem) yard1mıyla veriler toplanmıştır. Verilerin elde edilmesi aşamasında video çekimler ile saha gözlemleri farklı günlerde içerisinde tüm saat aralıklarını kapsayacak şekilde yapılmıştır. Verilerin elde edilmesi aşamasında bilgisayar ortamına aktarılan çekimler ile saha gözlemleri $15^{\prime}$ er dakikalık süreler için yapılarak incelenen yol kesimlerindeki trafik akım oranları belirlenmiştir (Şekil 3). Belirlenen akım oranları kullanılarak günlük ve aylık bazlı şerit dağılımlarına göre tahmini araç sayıları elde edilmiş ve analizlerde kullanılmıştır. 


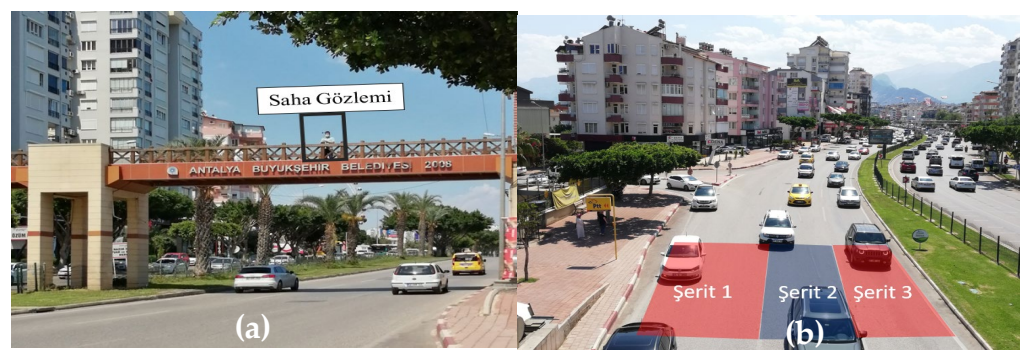

Şekil 3. Verilerin toplanması için yapılan (a) saha gözlemleri ile (b) video kamera çekimleri

\section{Bulgular}

Pandemi boyunca hem Covid-19 tehdidine tedbir olarak evde kalma ve uzaktan çalışma, online eğitim/öğretim hem de yasaklar sebebiyle tahmini günlük ve aylık araç sayılarındaki değişimi irdelemek amacıyla belirlenen noktalarda 1 Eylül 2020 - 31 Mayıs 2021 tarihleri arasında sayımlar yapılarak veriler analiz edilmiştir. 2020 yılı eylül ayından 2021 yılı mayıs ayı sonuna kadar elde edilen verilerden günlük bazda (günlere göre değişen araç sayıları) araç sayılarındaki değişimler tespit edilen veriler doğrultusunda hazırlanan Şekil 4-10'da verildiği şekilde elde edilmiştir.



Şekil 4. Aylara göre pazartesi günü araç sayılarında tespit edilen değişim

Şekil 4'te, pazartesi günü araç sayılarında meydana gelen değişimler verilmektedir. Şekil incelendiğinde şehrin farklı iki kesimi olan Nokta-1 (PTT) 
ile Nokta-2'ye (Vatan) ait eğriler ve Nokta-3 (Belediye) ile Nokta-4'e (Makine Mühendisleri Odası) ait eğriler kendi içlerinde birbirlerine benzer özellikler göstermektedir. Diğer günlere ait şekiller de incelendiğinde benzerlikler bulunduğu için bölgesel karakteristik yönelimler olduğu çıkarımı yapılmıştır.

Pazartesi günü özelinde verilerin toplanmaya başlandığı eylül ayından itibaren Nokta 1 ve Nokta 2' de günlük araç sayıları sırasıyla 40 ve 45 bin dolaylarında iken mevsimsel şartlar ve tatil sezonunun kapanması ile ekim, kasım ve aralık aylarında önemli bir düşüş trendi gözlemlenmektedir. Aralık ayı itibari ile uygulanmaya başlayan ve nisan ayı sonuna kadar farklı saatlerde uygulanan sokağa çıkma kısıtlamalarının etkisi ile eğrilerde dalgalanmalar görülmektedir. Nokta 3 ve Nokta 4'e ait eğriler incelendiğinde ise diğer iki bölgeye benzer değişiklikler bulunduğu görülmüştür. Ancak bölgeler arası araç sayılarındaki bariz farklılıklar nedeniyle Nokta 1 ve Nokta 2'e ait eğrilerde sert kırıklıklar olsa da Nokta 3 ve Nokta 4'te meydana gelen değişimlerin daha az olduğu açıktır. Nisan ayındaki kısıtlamaların ardından, 30 Nisan 2021 tarihinde başlayıp 16 Mayıs 2021'e kadar süren tam kapanma tedbirleri araç sayılarında yıllardır görülmeyen düşüşlere sebebiyet vermiştir. Kısıtlamadan muaf çalışan kesimlerin pazartesi günü trafiğe çıkmasına rağmen bu tarihlerde 3'te 1'e varan düşüşler dört noktada da görülmüştür. Tam kapanma sürecinin ardından hafta içi akşam saatlerinde kısıtlamalar devam etse de araç sayıları kısıtlama öncesi seviyelere dönmüş, hatta şekilde de açıkça görüldüğü üzere tam kapanma sonrasında kapanma öncesine göre araç sayılarında bariz artışlar tespit edilmiştir. Bu duruma hem kapanma sürecinde sosyal etkinliklerden uzak kalan vatandaşların sosyal etkinliklere yönelimi hem de mevsimsel etkilerin sebep olduğu düşünülmektedir.

Salı, çarşamba ve perşembe günlerine ait araç sayılarındaki değişim ise Şekil 5-7'de verilmektedir. Şekil 5-7'de verilen salı, çarşamba ve perşembe günlerine ait grafikler incelendiğinde pazartesi gününe ait eğriyle benzerlikler gözlemlenmektedir. Nokta 1ve Nokta 2'de yaz aylarından sonra bir düşüş trendi hakimken, pazartesi gününde olduğu gibi aralık ayından sonra araç sayılarında dalgalanmalar gözlemlenmektedir. Yine benzer şekilde tam kapanma sürecinde tüm bölgelerde ani düşüşler, ayrıca kapanma sürecinin ardından da pazartesi gününde olduğu gibi kapanma öncesine göre araç say1larında artışlar görülmektedir. Nokta 3 ve Nokta 4'de de yine benzer eğriler olsa da 15 Aralık 2020 Salı günü görülen düşüşte, bölgedeki altyapı çalışmasinın etkisi olduğu söylenebilmektedir. 


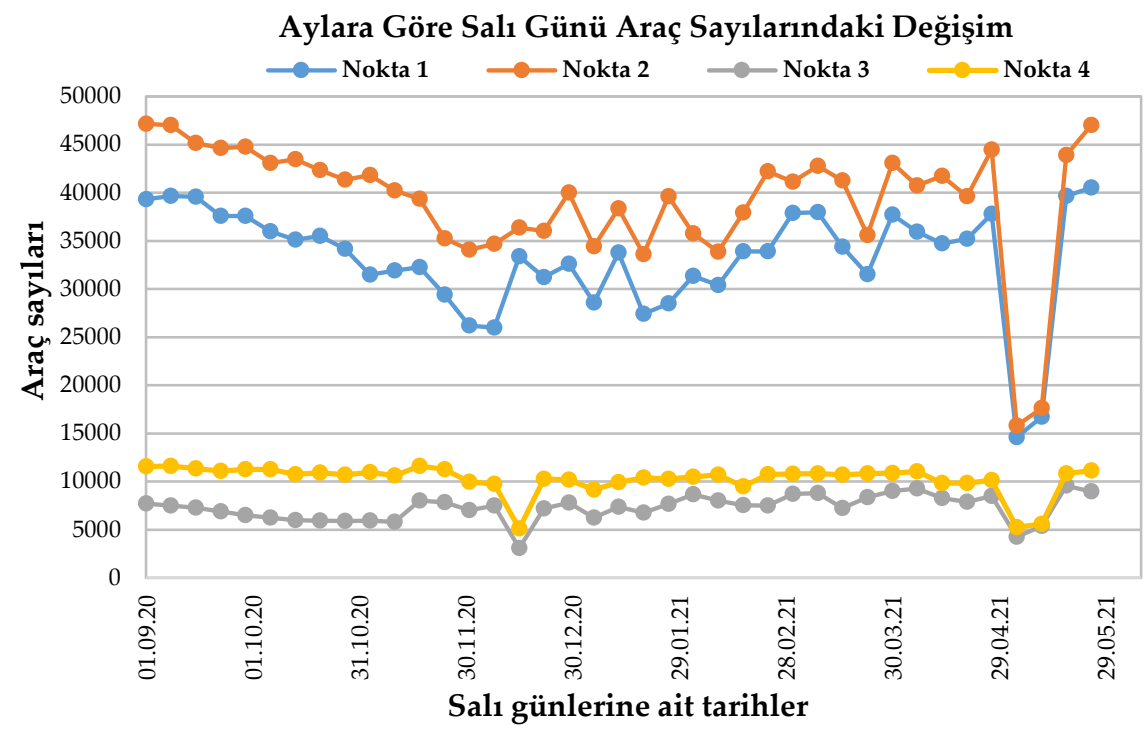

Şekil 5. Aylara göre salı günü araç sayılarında tespit edilen değişim

Aylara Göre Çarşamba Günü Araç Sayılarındaki Değişim

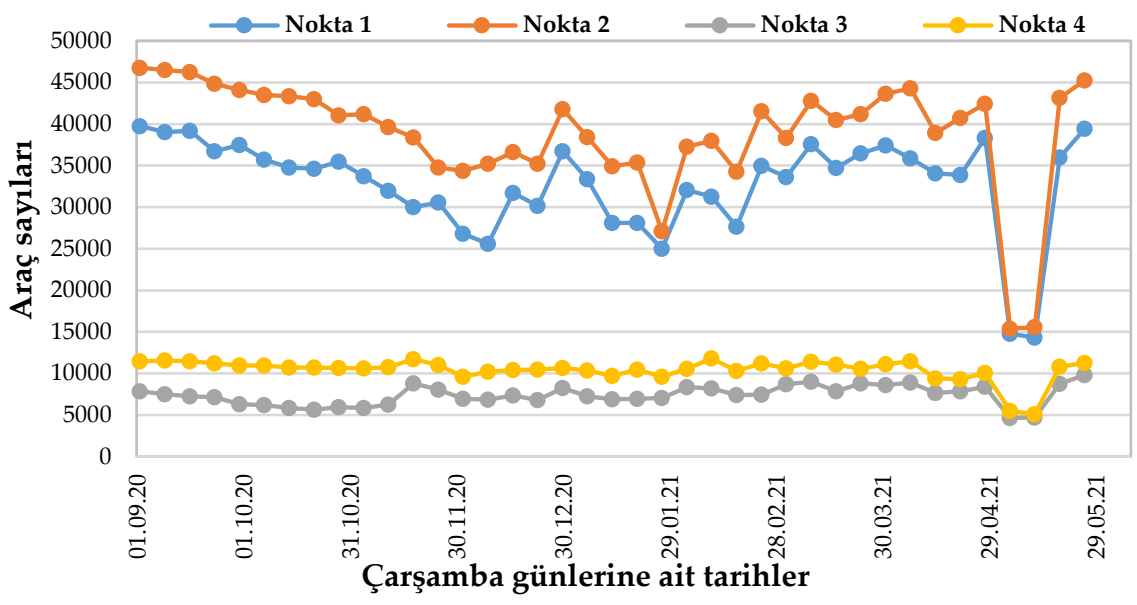

Şekil 6. Aylara göre çarşamba günü araç sayılarında tespit edilen değişim 


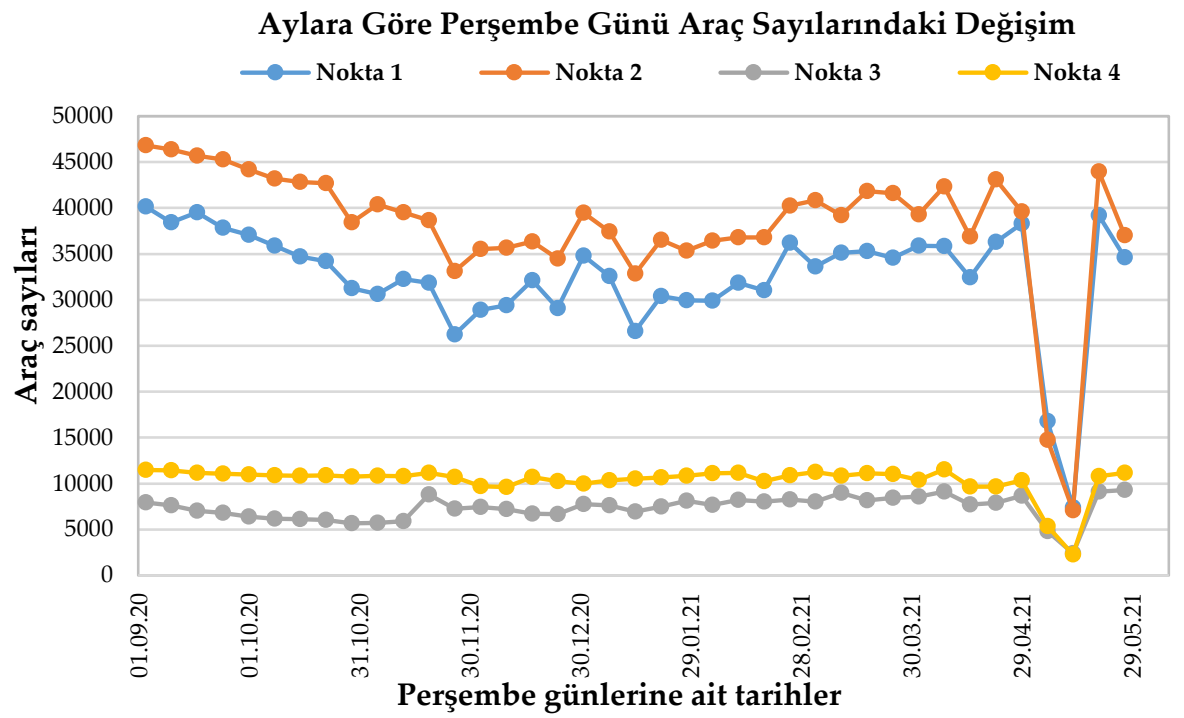

Şekil 7. Aylara göre perşembe günü araç sayılarında tespit edilen değişim

Cuma günü araç sayıları değişimi ile ilgili Şekil 8 incelendiğinde, yine hafta içi günlerle benzerlikler olsa da iki farklı tarihteki bariz değişimler son derece dikkat çekmektedir. Bunlardan ilki 1 Ocak 2021 tarihi olup bu tarihte yılbaşı tatili, hafta sonu sokağa çımma kısıtlamaları ile birleştirilerek üç günlük bir kısıtlama uygulanmıştır. 1 Ocak tarihinde uygulanan sokağa çıma kısıtlaması nedeniyle bugünde tüm bölgelerde büyük düşüşler gözlemlenmiştir. Dikkat çekici diğer bir farklılık ise tam kapanma kısıtlamalarının uygulandığı tarih aralığındadır. Bu dönemde, tüm bölgelerde düşük araç say1ları görülürken 7 Mayıs 2021 Cuma gününde büyük bir artış bulunmaktadır. Bu gündeki artışın ise Ramazan Bayramı nedeniyle verilen 9 günlük tatil öncesi kısıtlama dönemi istisnalara sahip vatandaşların tatil hareketleri nedeniyle gerçekleştiği çıkarımı yapılabilir. 


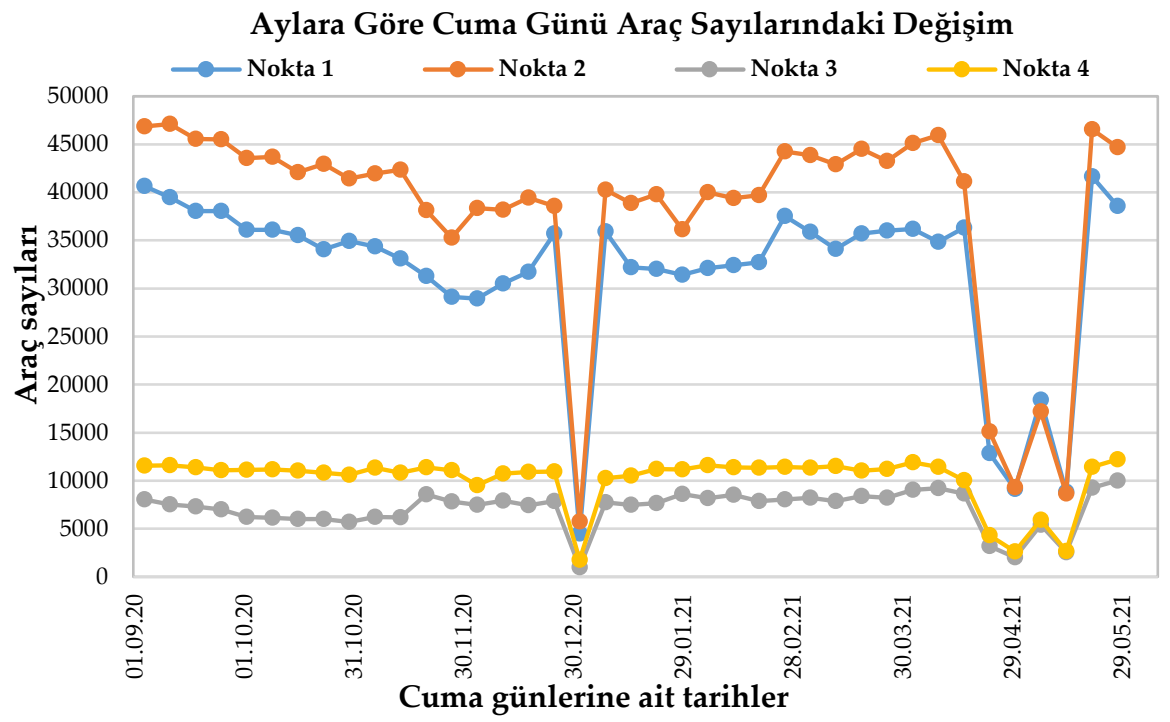

Şekil 8. Aylara göre cuma günü araç sayılarında tespit edilen değişim

Hafta içi günlerde birbirlerine benzer grafikler görülse de geniş döneme yayılan hafta sonu yasaklar nedeniyle cumartesi ve pazar günleri grafiklerinde büyük farklılıklar bulunmaktadır. Şekil 9'da verilen cumartesi gününe ait araç sayılarındaki değişime ait grafik incelendiğinde, kasım ayı sonunda uygulanan 20:00-10:00 saatleri arası sokağa çıkma kısıtlaması nedeniyle düşüşler gözlenmiştir.

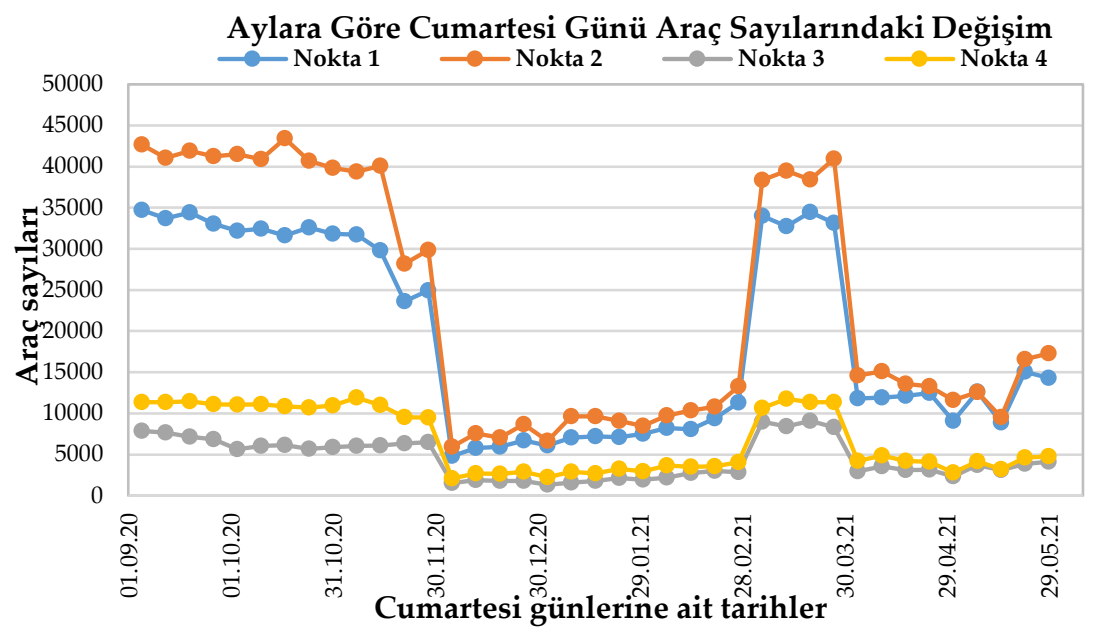

Şekil 9. Aylara göre cumartesi günü araç sayılarında tespit edilen değişim 
Yine şekil 9'dan da görüldüğü üzere 5 Aralık 2020 tarihi itibari ile gün boyu için başlayan sokağa çıma yasakları nedeniyle önceki döneme göre tüm bölgelerde daha keskin düşüşler gözlemlenmektedir. Aralıksız olarak mart ayına kadar devam eden yasaklardan dolayı, cumartesi günü araç say1ları düşük seviyede görülmüştür. Mart ayı itibari ile normalleşme adımları atılmış ve hafta sonu uygulanan yasaklar kaldırılarak vaka oranlarına göre kısmi illerde (Antalya dahil) pazar günleri yasaklar devam etmiştir. Mart ayında cumartesi günleri, Antalya'da sokağa çıkma kısıtlamaları olmaması nedeniyle araç sayılarında tüm bölgelerde artışlar olmuştur. Artan vaka sayıları ile birlikte nisan ayı itibari ile tekrar cumartesi günü sokağa çıkma kısıtlaması uygulamasına geçilmiş ve bu sebeple araç sayılarında tekrar önemli düşüşler yaşanmıştır.

Son olarak Şekil 10'da pazar gününe ait araç sayıları verilmiştir. Hafta içi günlerde kendi içlerinde benzerlikler olduğu gibi hafta sonu günlerde de birbirine benzer durumlar gözlemlenmektedir. Pazar gününe ait grafik incelendiğinde cumartesi gününde olduğu gibi saatlik kısttlamaların etkisi ile 22-29 Kasım tarihinde araç sayılarında düşüşler görülmektedir. Bu tarihten sonra, 2020 Ramazan Bayramı nedeniyle uygulanan dört günlük kısıtlamanın ardından ilk kez 5 Aralık 2020 Cumartesi gününde yasaklar başlamış ve pazar günleri için aralıksız olarak (Antalya için) günümüze kadar devam etmiştir. Mart ayı içerisinde uygulanan kısmi normalleşme faaliyetleri ile cumartesi günü araç sayılarında artış olduğu belirlenmiştir. Ancak, ilgili şekil incelendiğinde 6 Aralık 2020'den beri süregelen pazar günü yasakları nedeniyle araç sayılarının düşük seviyede seyrettiği tespit edilmiştir. Bahsi geçen mart ayındaki kısmi normalleşme döneminde, cumartesi günü uygulanan yasakların kaldırılması ile pazar günü için de grafikte görüldügü üzere hafif bir hareketlenme olmakta birlikte bunun nedeninin yaklaşık üç ay devam eden hafta sonu kısıtlamalarının psikolojik etkisiyle halkın kurallara riayet etmeme eğiliminin olduğu düşünülmektedir. 


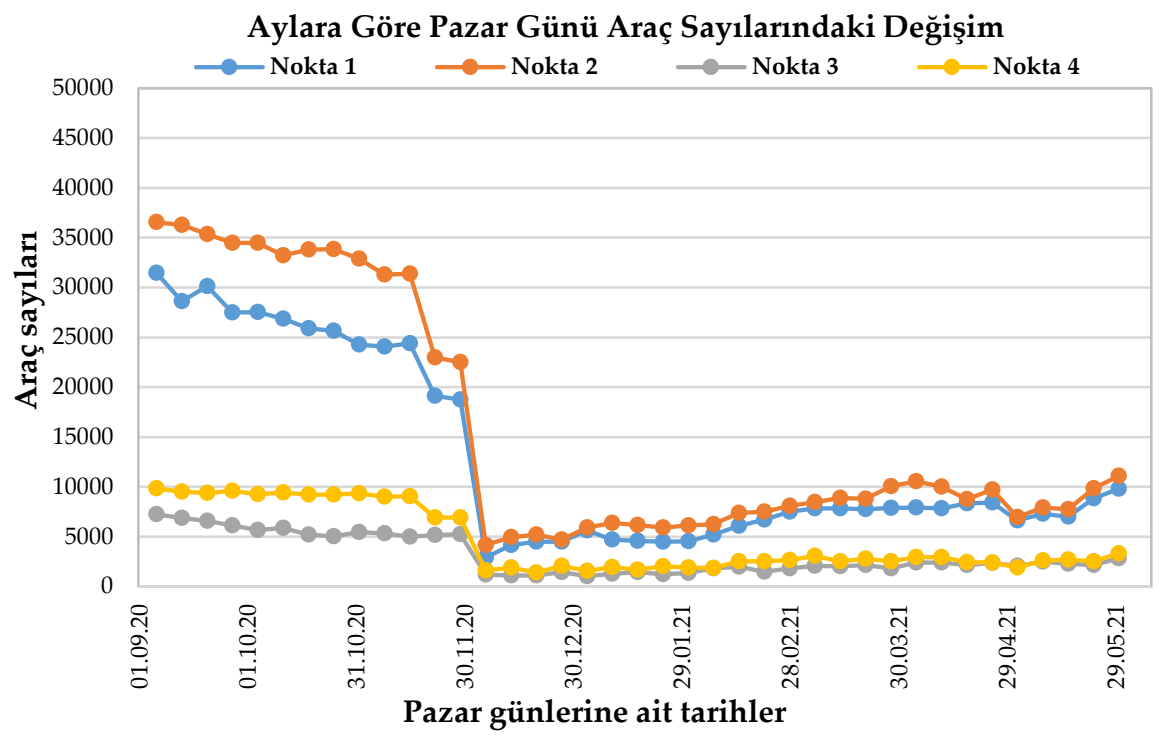

Şekil 10. Aylara göre pazar günü araç sayılarında tespit edilen değişim

Şekil 11'de ise çalışmanın yapıldığı döneme (Eylül 2020 - Mayıs 2021) ait veriler aylık bazda kümülatif olarak verilmiştir. Grafikte ortalama günlük hafta içi ve hafta sonu araç sayıları farklı renklerle gösterilmiştir. Araç sayıları incelendiğinde herhangi bir kısıtlama uygulanmayan eylül, ekim ve kasım aylarında hafta içine göre hafta sonu araç sayıları beklenildiği üzere daha az olsa da oransal olarak birbirine yakındır. Örneğin eylül ayında Nokta 1 için hafta içi 38761 hafta sonu 31696 araç, ekim ayında Nokta 4 için hafta içi 10910 hafta sonu 10196 araç olmak üzere hafta içi ve hafta sonu ortalama araç say1larında büyük farklılıklar bulunmamaktadır. 2020 Aralık, 2021 ocak ve şubat aylarında ise hafta sonu yasaklamaları ile birlikte ortalama hafta içi ve hafta sonu araç sayılarında çok büyük farklılıklar görülmüş ve aradaki fark açılmıştır. Örneğin 2021 yılı ocak ayında Nokta 2 için hafta içi 35184 hafta sonu 7390 araç, şubat ayında Nokta 3 için hafta içi 8024 hafta sonu 2226 araç sayıları elde edilmiştir. Bu da göstermektedir ki hafta sonu uygulanan yasaklarla birlikte mevcut araç hareketliliği hafta sonu büyük oranda azalmıştır. Mart ayı kısmi normalleşmesi ile birlikte cumartesi serbestliği sonucu hafta sonu ortalama araç sayısı elde edilen verilerle hazırlanan Şekil 11'den de anlaşıldığ üzere artmıştır. Nisan ve mayıs aylarında cumartesi yasaklarının tekrar başlaması sebebiyle hafta sonu araç sayısı oranlarında düşüş olsa da tam kapanma sürecinde hafta içi araç sayılarının azalması nedeniyle mayıs ayında hafta içi araç sayılarının da düştüğü söylenebilmektedir. 




Şekil 11. Aylara göre incelenen noktalardaki günlük trafik akım oranındaki dağılım

Tablo 3'te belirlenen dönemlerdeki araç sayılarındaki değişimler günlük olarak verilmiş olup günlük araç sayılarının dönemsel değişimleri ile pandemi ve yasaklamaların etkisi daha net görülmektedir. Verilerin toplandığ Eylül 2020 - Mayıs 2021 dönemleri tabloda 3 gruba ayrılmıştır. İlk dönem 2020 eylül ve aralık ayları arası, ikinci dönem 2021 ocak ve mart ayları arası, son dönem ise 2021 nisan ve mayıs aylarıdır. Dönemlerin seçimlerinde kısıtlama durumları belirleyici olmuştur. Son olarak da veri toplama dönemi 2020 eylül ve 2021 mayıs arası ortalamaları verilmiştir.

Veriler incelendiğinde hafta içi günlerde dönemler arası büyük farklılıklar gözlemlenmemiştir. Ancak cumartesi gününe baktığımızda, ilk dönemin ardından ikinci dönem hafta sonu uygulanan sokağa çıkma kısıtlamaları nedeniyle araç sayılarından ciddi düşüşler olduğu görülmektedir. Üçüncü dönem olan nisan ve mayıs ayları için cumartesi verileri incelendiğinde de tüm bölgelerde en düşük ortalama araç sayıları tespit edilmiştir. Pazar günü ve cumartesi günü verileri karşılaştırıldığında kısıtlamaların olmadığı ilk dönemde bile doğal bir farklılık bulunmaktadır. Pazar günü için ikinci ve üçüncü dönemlere de bakıldığında ikinci dönem (2021 ocak-mart) araç say1larının üçüncü döneme (2021 nisan-mayıs) göre daha fazla olduğu görülmektedir. Bu durumu daha önce de ifade edildiği üzere iyileşen mevsim şartları nedeniyle vatandaşların kurallara riayet etmeme eğiliminin tetiklediği söylenebilmektedir. Şekil 12' de ise aynı dönemlere ait veriler günlük verilmiştir.

Tablo 3. Araç sayılarındaki değişimin dönemsel bazda incelenmesi

\begin{tabular}{|c|c|c|c|c|c|c|}
\hline Dönem No & Dönem & GÜN & Nokta-1 & Nokta-2 & Nokta-3 & Nokta-4 \\
\hline 1 & Eylül-Aralık 2021 & \multirow{2}{*}{ Pazartesi } & 32680 & 39653 & 6650 & 10641 \\
\hline 2 & Ocak-Mart 2021 & & 33769 & 38767 & 8095 & 11000 \\
\hline
\end{tabular}




\begin{tabular}{|c|c|c|c|c|c|c|}
\hline 3 & Nisan-Mayıs 2021 & & 33994 & 37795 & 7959 & 9765 \\
\hline \multicolumn{3}{|c|}{ Genel Ortalama $(\bar{\mu})$} & 33536 & 39094 & 7454 & 10581 \\
\hline 1 & Eylül-Aralık 2021 & \multirow{3}{*}{ Salı } & 33504 & 40565 & 6616 & 10513 \\
\hline 2 & Ocak-Mart 2021 & & 32871 & 38436 & 7834 & 10403 \\
\hline 3 & Nisan-Mayıs 2021 & & 31899 & 36358 & 7762 & 9205 \\
\hline \multicolumn{2}{|c|}{ Genel Ortalama $(\bar{\mu})$} & & 33113 & 39161 & 7285 & 10235 \\
\hline 1 & Eylül-Aralık 2021 & \multirow{3}{*}{ Çarşamba } & 33545 & 40572 & 6892 & 10813 \\
\hline 2 & Ocak-Mart 2021 & & 32344 & 37946 & 7896 & 10676 \\
\hline 3 & Nisan-Mayıs 2021 & & 30825 & 35718 & 7596 & 9118 \\
\hline \multicolumn{2}{|c|}{ Genel Ortalama $(\bar{\mu})$} & & 32746 & 38860 & 7396 & 10436 \\
\hline 1 & Eylül-Aralık 2021 & \multirow{3}{*}{ Perşembe } & 33189 & 40109 & 6791 & 10701 \\
\hline 2 & Ocak-Mart 2021 & & 32261 & 38000 & 8004 & 10841 \\
\hline 3 & Nisan-Mayıs 2021 & & 30754 & 33792 & 7510 & 9021 \\
\hline \multicolumn{2}{|c|}{ Genel Ortalama $(\bar{\mu})$} & & 32520 & 38174 & 7360 & 10377 \\
\hline 1 & Eylül-Aralık 2021 & \multirow{3}{*}{ Cuma } & 34199 & 41507 & 6969 & 10976 \\
\hline 2 & Ocak-Mart 2021 & & 31737 & 38365 & 7533 & 10449 \\
\hline 3 & Nisan-Mayıs 2021 & & 26314 & 30412 & 6599 & 8067 \\
\hline \multicolumn{2}{|c|}{ Genel Ortalama $(\bar{\mu})$} & & 31725 & 38037 & 7100 & 10143 \\
\hline 1 & Eylül-Aralık 2021 & \multirow{3}{*}{ Cumartesi } & 24694 & 31077 & 5192 & 8803 \\
\hline 2 & Ocak-Mart 2021 & & 15864 & 18832 & 4180 & 5693 \\
\hline 3 & Nisan-Mayıs 2021 & & 12034 & 13795 & 3328 & 4112 \\
\hline \multicolumn{2}{|c|}{ Genel Ortalama $(\bar{\mu})$} & & 19086 & 23304 & 4494 & 6750 \\
\hline 1 & Eylül-Aralık 2021 & \multirow{3}{*}{ Pazar } & 19922 & 25094 & 4519 & 7104 \\
\hline 2 & Ocak-Mart 2021 & & 6199 & 7374 & 1641 & 2271 \\
\hline 3 & Nisan-Mayıs 2021 & & 8002 & 9176 & 2332 & 2635 \\
\hline \multicolumn{3}{|c|}{ Genel Ortalama $(\bar{\mu})$} & 12892 & 15808 & 3125 & 4532 \\
\hline
\end{tabular}
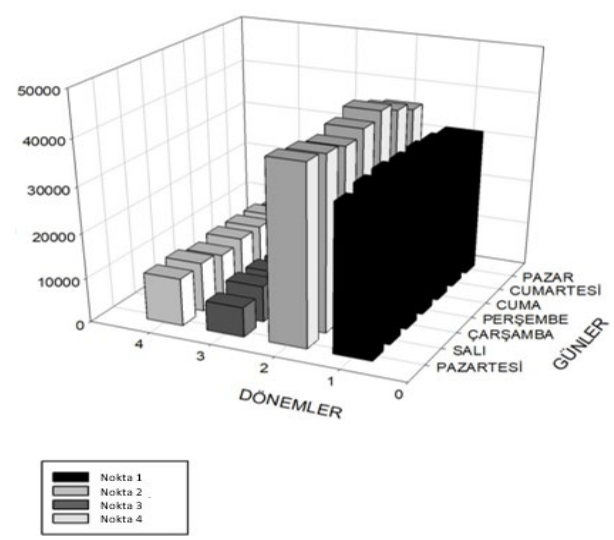

Şekil 12. Dönem ve günlere göre tespit edilen ortalama araç sayıları 
Şekil 13'te pandemi nedeniyle en yoğun kısıtlamaların uygulandığı nisan ve mayıs aylarına ait araç sayıları verilmiştir. Bu aylarda hafta sonu günlerde gün boyu sokağa çıkma kısıtlaması uygulanırken hafta içi günlerde akşam saatlerinden sonra sokağa çıkma kısıtlaması uygulanmıştır. Şekilde her dairesel eğri 5000 araca karşıllk gelmekte olup veriler incelendiğinde hafta sonu araç değerlerinde hafta içi günlere göre keskin düşüşler olduğu açıkça görülmektedir. Tam kapanma kısıtlamalarının uygulandığı 30 Nisan - 16 Mayıs 2021 tarihleri arasında da araç sayılarının oldukça düşük değerlerde seyrettiği grafikte görülmektedir.

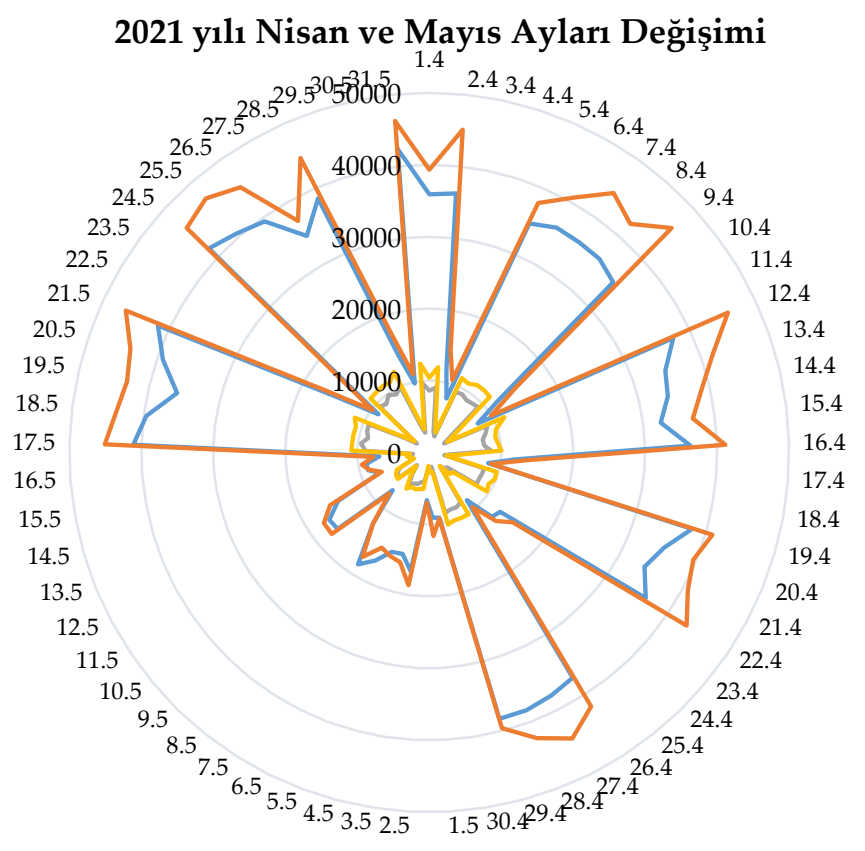

Nokta 1

Nokta 2

Nokta 3

Nokta 4

Şekil 13. Nisan ve mayıs ayları için elde edilen günlük trafik akım oranı değişimi

\section{Tartışma ve Sonuç}

2019 yılının sonlarında Çin'in Wuhan şehrinde ortaya çıkan; kısa sürede k1taları, ülkeleri ve şehirleri etkisine alarak günlük hayat rutinlerimizde büyük değişimlere sebebiyet veren COVID-19 pandemisinin ulaşım alanında önemli değişimlere neden olduğu yadsınamaz bir gerçektir. Bu çalışma kap- 
samında, pandemi sürecindeki uzaktan eğitim ile uzaktan çalışma, bulaş korkusu nedeniyle evde kalma ve sokağa çıma kısıtlamalarının, trafikteki araç sayıları üzerinde nasıl bir etkiye neden olduğunu irdelemek amaciyla pilot şehir olarak belirlenen Antalya'da farklı dört bölgede incelemeler yapılmıştır. Video kamera çekimleri ile saha gözlemlerinden elde edilen akım oranı verileri incelendiğinde aşağıda verilen sonuçlara ulaşılmıştır.

- Vaka sayılarının çok yüksek olmadığı ve herhangi kısıtlamaların uygulanmadığı 2020 yılı eylül, ekim, kasım aylarına ait araç sayıları, incelenen döneme göre genel olarak yüksek dilimde kalmakla birlikte mevsimsel etkilerle tüm bölgelerde aydan aya azalış eğilimindedir.

- 2020 Aralık ayı ile birlikte hafta içi akşam saatlerinde hafta sonu ise tüm günü kapsayacak şekilde kisıtlamalar uygulanmaya başlamıştır. Uygulanan kısıtlamalar ile birlikte hafta içi araç sayılarında ufak düşüşler görülmekle birlikte hafta sonu günlük bazda \%92'ye varan düşüşler belirlenmiştir.

- 2020 Aralık ayı ile başlayan hafta içi günlerde akşam saatlerindeki sokağa çıkma kısıtlamaları, mayıs ayı sonuna kadar devam etmiştir. Tam kapanmanın uygulandığı hafta içi günler haricindeki diğer (sadece akşam kısıtlamaları olan) hafta içi günlerde genellikle birbirine yakın araç sayıları görülmektedir.

- 2020 Aralık - 2021 Mayıs dönemine bakıldığında genellikle hafta sonu sokağa çıkma yasakları uygulanırken, kısmi normalleşme dönemi olan mart ayında cumartesi günleri yasakları kaldırılmıştır. Bu dönemde aralık ayı öncesi yasakların uygulanmadığı dönemdeki verilere yakın araç sayıları elde edilmiştir.

- Tam kısitlamaların uygulandığı 30 Nisan 2021 - 16 Mayıs 2021 arası verilere bakıldığında da şaşırtıcı şekilde, önceki dönem hafta sonu yasaklarındakilerden fazla araç sayıları görülmektedir. Bu durum üzerinde tam kısıtlama dönemi muafiyeti bulunan çalışanların sebep olduğu düşünülmektedir.

Tüm bu bilgiler, veriler ve grafikler ışığında pandemi sürecinin araç sayılarındaki büyük ve düzensiz değişimlere neden olduğu yadsınamaz bir gerçektir. İncelenen bu dönemde bireysel araç sahipliliği oranı artmasına rağmen nazara alınan bölgelerdeki araç sayılarının genellikle vaka sayılarının düşük olduğu Eylül-Ekim dönemine göre daha düşük bantta seyrettiği sonucuna ulaşılmaktadır. Bu sonuç, insan yaşamını olumsuz etkileyen bu tür virüslerin ortaya çıkması ile birlikte insan hayatında ve özellikle ulaşım hare- 
ketliliğinde büyük değişimler olabileceğini, pilot kent Antalya ölçeğinde Türkiye için ortaya koymuştur. Bu çalışmadan elde edilen bulgulara göre, virüs vb. nedeniyle görülebilecek kaos, kısıtlamalar vb. sınırlayıcı etmenlerin ulaşım plancılarının planlama süreçlerinde bir karmaşaya neden olabileceği net bir şekilde görülmektedir. Bundan sonra yapılacak planlama çalışmalarında, virüslerin de artık insan yaşamını ve ulaşım hareketliliğini doğrudan etkileyen bir etmen olarak değerlendirilmesi gerektiği bu çalışmanın önemli bir sonucu olarak ön plana çıkmıştır. Dolayısıyla sağlıklı planlama ve araştırmalar yapılabilmesi için bu çalışmada olduğu gibi diğer şehirlerde de bu sürece ait trafik akım, ulaşım hareketliliği vb. verilerin toplanmasının, ileri ki süreçte yapılacak planlamalar için oldukça faydalı olabileceği düşünülmektedir. Böylece gelecekte yapılacak planlama ve araştırma çalışmalarında virüs öncesi, virüsün gözlemlendiği süre ve sonrasına ait veriler birbirleriyle istatistiksel ya da yapay zekâ yöntemleri yardımıyla karşılaştırılarak sağlıklı ve bilimsel tabanlı öneriler geliştirilebilecektir. 


\title{
Extended Abstract
}

\section{Investigation of Changes in Traffic Flows due to COVID-19 Restrictions in Urban Main Arterials: Example of Antalya}

\author{
Eren Dağlı \\ Metin Mutlu Aydın \\ ORCID:0000-0002-3892-0270 \\ ORCID:0000-0001-9470-716X \\ Emine Çoruh
}

ORCID: 0000-0002-3251-9179

The COVID-19 Pandemic, which emerged in China at the end of 2019, has started to show its effect rapidly in daily life around the world since the first months of 2020. With the effects of the pandemic, it has caused restrictions and changes in order in many areas all over the world, especially in Europe and America. As in education, health, trade and social areas, great changes have been seen in transportation services and transportation characteristics due to the COVID-19 pandemic. Compared to other countries, the first case in Turkey was detected on March 11, 2020 in Istanbul, as a matter of fact, later than other countries. Following the detection of the first case, face-to-face education was suspended as of March 16, 2020, and online education was started. Large companies also adopted the remote or shift working order in this period. These changes implemented due to the pandemic have caused great differences in community life. Mobility of students and employees is restricted with applications such as online education or remote working. Thus, it was aimed to reduce the density and to implement the social distance rule. These changes in daily life have also been supported by changes in public transport policies. For this purpose, as a first measure in the field of transportation, as of March 23, 2020, it has been allowed to carry passengers up to $50 \%$ of the vehicle capacity in urban public transportation vehicles. Following the course of the pandemic from the date the first case was detected, and depending on the increase in the number of citizens infected with the virus, curfews were imposed in some periods, either regionally or throughout the country. Thus, it is aimed to slow 
down the spread of the virus and to prevent the increase in the total number of cases. There were different applications for some age groups in the restrictions. The number of regional cases and the rate of increase in cases were decisive in the determination and implementation of these restrictions. Due to the curfews that differ for various cities, regions, days and age groups, changes have started to be seen in many areas related to transportation. These can be expressed as changes in public transport frequency, changes in the number of passengers using urban public transport services, changes in the number of vehicles in traffic, and changes observed in intercity train, bus and plane travel. Differences have been observed in individual vehicle use, as in public transportation or intercity public travel vehicles. For example, instead of personnel shuttles, there are applications to travel by automobiles. These and similar applications can also cause sudden increases in the number of existing vehicles in traffic. Antalya, which is one of the leading cities of Turkey in terms of population and number of vehicles, was chosen in order to examine the changes in the number of vehicles in the traffic within the scope of this study in order to determine similar situations scientifically. Four different points have been determined on the main arteries located in the city center of Antalya, which stands out with tourism, industry and agricultural activities, which is determined as a pilot city, where the traffic continues throughout the day (on Atatürk Boulevard and Bülent Ecevit Boulevard). In order to determine the number of vehicles in the determined regions, existing regional data were collected with the help of camera shots and field observations. The collected data were digitized in the computer environment. With the numerical data obtained, the changes in the number of vehicles in traffic due to the effect of the pandemic were examined in detail. When the results obtained as a result of comprehensive evaluations on the number of vehicles are examined in detail, there are generally similar situations on weekdays. However, when the number of vehicles in traffic at the weekend is examined, a significant decrease has been detected in the number of vehicles in traffic on the days when curfews are applied. Therefore, there are great differences in the number of vehicles and fluctuations in the graphics between weekdays and weekends, or between the days when curfews are applied or not. When the available data, graphics and information were evaluated comprehensively, it was determined that the pandemic process caused sharp and irregular changes in the number of vehicles. Although the rate of individual vehicle ownership increased regularly during the period under review, it was observed that the number of vehicles in traffic on days other than restriction days was close to the number before the pandemic. This result confirms that 
due to the pandemic, citizens tend to use individual vehicles instead of public transport. With the increase in individual vehicle usage rates, the existing capacity and infrastructure in urban centers may cause new problems. For example, it is predicted that with this increase in the number of vehicles in traffic, various traffic density and jam problems may be seen. The pandemic process, which has been affecting community life around the world for a long time, and the observed effects of this process are seen as an important effect in terms of traffic planning in the coming years. Therefore, in the traffic planning to be made by researchers and local administrations, the pre-virus, virus period and post-virus period should be compared with each other by statistical methods and artificial intelligence studies. The determinations made at four different points determined in Antalya are presented to researchers as a study summarizing the differing traffic habits during the pandemic period.

\section{Kaynakça/References}

Abu-Rayash, A., ve Dincer, I. (2020). Analysis of mobility trends during the COVID-19 coronavirus pandemic: Exploring the impacts on global aviation and travel in selected cities. Energy Research and Social Science, 68, 101693.

Aloi, A., Alonso, B., Benavente, J., Cordera, R., Echániz, E., González, F., ve Sañudo, R. (2020). Effects of the COVID-19 lockdown on urban mobility: Empirical evidence from the city of Santander (Spain). Sustainability, 12(9), 3870.

Andara, R., Ortego-Osa, J., Gómez-Caicedo, M. I., Ramírez-Pisco, R., Navas-Gracia, L. M., Vásquez, C. L., ve Gaitán-Angulo, M. (2021). Behavior of traffic congestion and public transport in eight large cities in Latin America during the COVID-19 pandemic. Applied Sciences, 11(10), 4703.

Arslan, T., ve Murat, Y. S. (2011). Kent ulaşımında organizasyonel sorunların değerlendirilmesi: Antakya örneği. Pamukkale Üniversitesi Mühendislik Bilimleri Dergisi, 17(1), 33-41.

Bbc (2021). Covid-19 Türkiye istatistikleri. 22.02.2021 tarihinde https://www.bbc.com/turkce/haberler-turkiye-51828267 adresinden erişildi.

Beck, M. J., ve Hensher, D. A. (2020). Insights into the impact of COVID-19 on household travel and activities in Australia-The early days under restrictions. Transport Policy, 96 (Sep), 76-93.

Brookings Institute (2020). Coronavirus has shown us a world without traffic. Can we sustain it? 15.05.2020 tarihinde https://www.brookings .edu/research/coronavirus-has-shown-us-a-world-without-traffic-can-weustain-it/. adresinden erişildi.

Chinazzi, M., Davis, J. T., Ajelli, M., Gioannini, C., Litvinova, M., Merler, S., ve Vespignani, A. (2020). The effect of travel restrictions on the spread of the 2019 novel coronavirus (COVID-19) outbreak. Science, 368(6489), 395-400. 
Cruz, C. O., ve Sarmento, J. M. (2021). The impact of COVID-19 on highway traffic and management: The case study of an operator perspective. Sustainability, 13(9), 5320.

De Vos, J. (2020). The effect of COVID-19 and subsequent social distancing on travel behavior. Transportation Research Interdisciplinary Perspectives, 5, 100121.

Ekergil, V., ve Kodalak, E. (2020). COVID-19 sağlık krizinde raylı toplu taşımadaki maliyet sorununa bölgesel tarife önerisi: Eskişehir uygulaması. İşletme Akademisi Dergisi, 1(3), 275-293.

Erbaş O. (2020). COVID-19 döneminde hareketlilik: İstanbul kent içi toplu ulaşım. Kent Akademisi, 13(3), 431-442.

Euronews (2020). Avrupa'da koronavirüs yasakları 15.03.2020 tarihinde https://tr.euronews.com/2020/03/21/avrupa-da-hangi-ulkeler-koronavirussebebiyle-karantina-ve-sokaga-cikma-yasagi-uyguluyor adresinden erişildi.

Goenaga, B., Matini, N., Karanam, D., ve Underwood, B. S. (2021). Disruption and Recovery: Initial Assessment of COVID-19 Traffic impacts in North Carolina and Virginia. Journal of Transportation Engineering, Part A: Systems, 147(4), 06021001.

Guan, L., Prieur, C., Zhang, L., Prieur, C., Georges, D., ve Bellemain, P. (2020). Transport effect of COVID-19 pandemic in France. Annual Reviews in Control, 50(2020), 394408.

Huang, X., Ding, A., Gao, J., Zheng, B., Zhou, D., Qi, X., ve He, K. (2021). Enhanced secondary pollution offset reduction of primary emissions during COVID-19 lockdown in China. National Science Review, 8(2), nwaa137.

Institute of Transportation Engineers (2020). COVID-19 traffic volume trends. 30.09.2020 tarihinde https://www.ite.org/about-ite/covid-19-resources/covid-19-trafficvolume-trends/. adresinden erişildi.

İstanbul İstatistik Ofisi [İ̈O] (2020.) İstanbul Ulaşım Bülteni. İstanbul, Tükiye. İstanbul Büyükşehir Belediyesi.

Kopsidas, A., Milioti, C., Kepaptsoglou, K., ve Vlachogianni, E. I. (2021). How did the COVID-19 pandemic impact traveler behavior toward public transport? The case of Athens, Greece. Transportation Letters, 13(5-6), 344-352.

Le Quéré, C., Jackson, R. B., Jones, M. W., Smith, A. J., Abernethy, S., Andrew, R. M., ... ve Peters, G. P. (2020). Temporary reduction in daily global CO 2 emissions during the COVID-19 forced confinement. Nature Climate Change, 10(7), 647-653.

Liu, Z., ve Stern, R. (2021). Quantifying the traffic impacts of the COVID-19 shutdown. Journal of Transportation Engineering, Part A: Systems, 147(5), 04021014.

Mission Support Services (2020). Daily traffic volume trends. 01.10.2020 tarihinde https://www.ms2soft.com/traffic-dashboard/. adresinden erişildi.

Mutlu, Ö., Durak, Z., ve Akyer, H. (2020). Kademeli mesai saati ile trafik sıkışıklığının azaltılması. Pamukkale Üniversitesi Mühendislik Bilimleri Dergisi, 26(4), 730-736.

Tian, X., An, C., Chen, Z., ve Tian, Z. (2021). Assessing the impact of COVID-19 pandemic on urban transportation and air quality in Canada. Science of the Total Environment, 765, 144270. 
Türkiye Cumhuriyeti Sağlık Bakanlığı (2020). COVID-19 istatistikleri. 30.03.2020 tarihinde https://covid19.saglik.gov.tr/TR-66935/genel-koronavirustablosu.html adresinden erişildi.

Türkiye İstatistik Kurumu [TÜİK] (2021). TüİK Motorlu Kara Taşıtları Bülteni (Nisan 2021). Ankara, Türkiye. Türkiye İstatistik Kurumu.

University of Maryland (2020). COVID-19 impact analysis platform. 10.09.2020 tarihinde https://data.covid.umd.edu/. adresinden erişildi.

World Health Organization [WHO] (2020). Health statistics. 30.12.2020 tarihinde https://www.who.int/en/ adresinden erişildi. 